нергетичні засади моделювання освітніх систем: дис. ... канд. філос. наук: 09.00.03 / АПН України; Інститут вищої освіти. / А. В. Свтодюк. - К., 2002. - 198 с. 5. Клепко С. Ф. Інтегративна освіта і поліморфізм. / С. Ф. Клепко. - Київ-Полтава-Харків: ПОІПОПП, 1998. - 360 с. б. Мелехова О. П. Синергетика как общая методология современного образования в области наук о жизни / О. П. Мелехова. - Режим доступа http:// spkurdyumov.ru/ Meiexova.htm. 7. Мукушев Б. А. Синергетический подход к экологизации образования / Б. А. Мукушев // Вестник высшей школы. - 2008. № 10. - С. 30-37. 8. Назаретян А. Я. Синергетика в гуманитарном знании / А. Я. Назаретян // Общественные науки и современность. 1997. - № 2. - С. 91-98. 9. Назарова Т. С. Парадигма нелинейности как основа синергетического подхода в обучении / Т. С. Назарова, В. С. Шаповаленко // Стандарты и мониторинг в образовании. 2003. - № 1. - С. 3-11. 10. Синергетика в публічному управлінні: тлумачний словник / за ред. С. М. Серьогіна. - Д. : ДРІДУ НАДУ, 2007. - 48 с. 10. Федорова М. А. Педагогическая синергетика как основа моделирования и реализации деятельности преподавателя высшей школы: дис. ... канд. пед. наук. - 13.00.08 «Теория и методика профессионального образования» / М. А. Федорова. - Ставрополь, 2004. - 169 с. 11. Энциклопедия профессионального образования : в 3-х т. / под ред. С. Я. Батышева. - М, АПЩ 1998.- Т. 1А-Л-1998. -568 c.

УДК $373.5: 33$

В. С. Кулішов, викладач,

Криворізький економічний інститут ДВНЗ «Криворізький національний університет», аспірант, НАПН Украӥни

\title{
ДЕЯКІ ПРОБЛЕМИ ТА ПЕРСПЕКТИВИ РОЗВИТКУ ШКІЛЬНОЇ ЕКОНОМІЧНОЇ ОСВІТИ
}

У статті висвітлено сучасні тенденції здійснення економічної освіти та виховання у загальноосвітній школі, а також висловлено деякі припущчення щцодо перспектив подальшого розвитку ичього освітнього напряму.

Ключові слова: економічна освіта, икільна економічна освіта, ринкова економіка, навчальний план, старша профільна школа.

В статье рассмотрены современные тенденции осуществления экономического образования и воспитания в общеобразовательной школе, а также высказаны некоторые предположения относительно перспектив дальнейшего развития данного образовательного направления.

Ключевые слова: экономическое образование, школьное экономическое образование, рыночная экономика, учебный план, старшая профильная школа. 
The article highlights modern trends of economic education and training in secondary school, and expressed some assumptions about the future development of this educational movement.

Key words: economic education, school education in economics, market economics, curriculum, older profile school.

Зміни в житті сучасного суспільства пов'язані з особливим періодом його розвитку - епохою інформатизації та глобалізацією. Постійне збільшення інформації, поява нових технологій у науці й виробництві, посилення ролі всесвітніх економічних, політичних, правових, соціокультурних та інших форм відносин $є$ характерними для всіх сфер діяльності людини. Прагнення країн до стійкого соціальноекономічного розвитку підвищують суспільну значущість економічних знань для кожної людини як передумови якісного та безпечного споживання.

Розбудова громадянського суспільства, важливою умовою існування якого $є$ наявність грамотного активного споживача, неможлива без організації в масштабі всієї країни системного й комплексного впровадження економічного виховання і навчання в усіх формах і на всіх рівнях загальної середньої освіти. Економічна освіта є однією з головних форм адаптації людей до мінливих умов життя, заснованого на принципах ринкової економіки.

У зв'язку з цим оптимізація змісту та шляхів реалізації економічної освіти є одним із першочергових завдань роботи загальноосвітньої школи.

Проблема економічної освіти та виховання досліджується у вітчизняній педагогічній науці не один рік. На увагу заслуговують праці вчених, присвячені проблемам шкільної економічної освіти в сучасних умовах ринкового господарювання: М. Вачевського, В. Мадзігона [2],

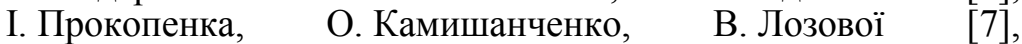
А. Нісімчука [4], О. Падалки [5], О. Шпака [8] та інших.

Mema cmammi - проаналізувати сучасний стан та подальші перспективи розвитку економічної освіти та виховання в загальноосвітній школі.

Економічна освіта - освіта, спрямована на аналіз та висвітлення зв'язків, які існують у ринковій економіці між людиною, родиною i державою, вивчення ключових економічних концепцій i законів, розуміння основних впливів економічного середовища на діяльність підприємця, 
формування особистої та фахової компетентності. Економічна освіта як складова загальної середньої освіти населення має провідне значення в умовах ринкових перетворень та демократизації суспільства, оскільки без глибоких економічних знань, належної підготовки фахівців країна не може досягти динамічного розвитку [3, с. 250].

Метою економічної освіти в системі загальної середньої освіти є така підготовка учнів, яка забезпечить їм достатній рівень життєвої компетентності у сфері економічних відносин на рівні держави, родини та окремої людини. О. Аксьонова вважає, що центральною метою економічної освіти можна вважати формування економічного мислення, а ii результатом економічно-обгрунтовану практичну діяльність, що приносить прибуток [1, с. 60-61]. Загалом, дослідниця переконана, що рівень економічної освіти має розглядатися в контексті рівня розвитку економіки країни [1, c. 57].

Зміст шкільного курсу економіки побудовано отже, щоб він зміг реалізувати мету i завдання курсу, сформувати основні базові знання з основ економічної науки, ознайомити 3 основними тенденціями розвитку економіки (науки i господарства) на сучасному етапі, отримати майбутню спеціалізацію з обраного профілю.

Національна освіта робить значні кроки у становленні шкільної економічної освіти, але коло невирішених питань охоплює ще багато проблем: зміст i терміни навчання, варіативність i різноманітність програм, навчальнометодичне забезпечення та його якість, підготовка i перепідготовка вчителів 3 економіки. Таких проблем у вивченні економіки значно більше, ніж з інших дисциплін.

Нині вивчення економіки в школі має забезпечувати: а) розвиток економічної культури, економічного мислення учнів спрямований на критичний аналіз процесів i результативність діяльності; б) формування умінь самостійно набувати, засвоювати і застосовувати економічні знання, спостерігати і пояснювати сучасні економічні явища; в) розширення уявлень про професійну діяльність у сфері економіки, отримання i закріплення навичок обраного профілю; г) забезпечення рівня економічної підготовки, що дозволить старшокласникам гідно продовжити навчання на економічних та інших факультетах вищих навчальних 
закладах, у сфері професійно-технічної освіти, коледжах економічного профілю.

У навчальні плани економіку введено як окремий предмет для 11 класів, а для профільних класів - і в 10. На конкурсізахисті Малої академії наук працюють секції, на яких учні захищають творчі роботи 3 економіки. Розроблено орієнтовну програму підготовки i перепідготовки для вчителів, що проходять іiі в інститутах післядипломної педагогічної освіти. У старшій школі, як профільній, зміст предмету «Економіка» представлений окремими спеціальними курсами, які враховують інтереси, здібності та життєві плани учнів з одного боку, і відповідають профілю школи 3 іншого. До варіативної частини профільної школи віднесено такі економічні курси: «Основи підприємницької діяльності», «Власна справа», «Основи менеджменту», «Основи інтелектуальної власності», «Основи споживчих знань», «Основи сімейного господарювання» тощо.

Основними завданнями курсів за вибором є забезпечення вивчення економіки і споріднених 3 нею предметів на достатньому рівні. 3 їх допомогою відбувається трансформація отриманих фахових знань учнів в їх практичний досвід. Практичні роботи, екскурсії, презентації, дослідження, моделюючі або ситуативні вправи $\epsilon$ невід’ємною складовою виховання та підготовки майбутніх фахівців.

Робочі плани профільних класів, на нашу думку, можуть включати багато курсів за вибором і факультативів. Тим самим буде забезпечуватися гнучка система профільного навчання, яка надаватиме учням можливість обрати індивідуальну освітню програму, а робочі плани класів 3 поглибленим вивченням предмету, крім розширення i поглиблення змісту, мають сприяти формування стійкого інтересу до предмету, розвитку відповідних компетенцій i орієнтацій на професійну діяльність, пов'язану 3 обраним профілем. Поглиблене вивчення основ економіки, отже, буде здійснюється за спеціальними програмами, тобто доповнюється набором курсів за вибором певного спрямування, або за модульним принципом.

У НАПН України працюють лабораторії, що опікуються питаннями економічного навчання та виховання учнівської молоді. Чи не найголовнішим у тому, що зроблено за цей час, $\epsilon$ розуміння учнями та вчителями, що викладають курс 
«Основи економіки», необхідності та важливості вивчення предмета, а також прискорення введення економічних дисциплін в інших навчальних закладах, у тому числі вищих педагогічних.

Однією 3 найважливіших проблем сьогодення є питання як навчати? Щоб відповісти на нього, потрібно визначити для себе, чого ми хочемо навчати i кого виховувати? Якщо розумну, активну особистість, здатну здобувати знання i самовдосконалюватись, то форми, методи i технології навчання мають цьому відповідати.

Національна доктрина розвитку освіти у XXI ст., схвалена на Другому всеукраїнському з'їді працівників освіти, передбачає перехід від репродуктивної й авторитарної освіти до інноваційної і гуманістичної. Тому методика викладання предмета повинна мати дієвий характер. Учень на уроках має бути активним учасником навчального процесу. Основне завдання його полягає не в умінні повторити за вчителем або відтворити зміст підручника. Треба навчити його самостійно знаходити знання в різних джерелах інформації, критично оцінювати їx i застосовувати в реальному житті. О. Аксьонова 3 цього приводу зазначає, що навчити економіки неможливо, можна дати знання про основні принципи i закономірності, які утворюють підгрунтя для розвитку економічних інтересів, мислення й поведінки [1, c. 57].

Цього потрібно навчати не лише учнів, а й учителів. Учителеві, який багато років працював за репродуктивною системою і не використовує інші джерел інформації, важко змінитися. Значну роль у цьому покликані відіграти Інститут післядипломної педагогічної освіти, методисти 3 економіки, центри економічної освіти, вищі навчальні педагогічні заклади, що готують студентів і працюють з учителями.

Протягом найближчих років потребою часу є підготовка значної кількості вчителів 3 економіки. Вимоги, що висуваються до них, високі. Тому Міністерство освіти і науки України разом 3 Національною радою економічної освіти США, Українською радою розпочинає розробку навчально-методичного забезпечення курсів підвищення кваліфікації вчителів з економіки.

У цьому могли б сприяти також такі громадські організації, як Всеукраїнська асоціація викладачів економіки, економічні центри, асоціації, ради. Вони можуть впливати на 
підвищення якості навчально-виховного процесу, допомагаючи вчителям через консультаційні центри, семінари, тренінги; залучати вчителів до оцінювання якості посібників, що видаються у різних регіонах, та інформувати їх про це, брати участь у виховній та профорієнтаційній роботі i залучати громадськість до цього, проводити аналітичну, інформаційну i роз'яснювальну роботу, пов'язану з життєво важливими економічними питаннями, брати участь у видавничій діяльності тощо.

Вивчення економічних дисциплін у школі потребує забезпечення відповідною навчально-методичною літературою. Фактично в наявності $\epsilon$ лише збірник навчальних програм, кілька підручників i посібників 3 базового курсу, журнал «Географія та основи економіки в школі». Не достатньою є кількість методичних посібників, збірників завдань для уроків і підготовки до олімпіад, тестових завдань для перевірки навчальних досягнень учнів за 12-бальною системою.

Слід урахувати дидактичні принципи послідовності i наступності, доцільності і розумності викладу матеріалу, що пропонується до друку. Перед тим як розробляти будь-який навчальний посібник, необхідно з'ясувати його системне місце у шкільному курсі, навчальному плані, тобто він не може бути відірваним від загальної концепції сучасної економічної освіти. Неузгоджений за горизонталлю i вертикаллю матеріал ставить у незрозумілі ситуації навчальні заклади, особливо тих, що без вагань уводять економіку в 3 або 7 класі.

Не кожний шкільний предмет розкриває учневі можливості застосувати на практиці нові знання і вміння. Економіка таку можливість дає. Більше того, на iї уроках учні вивчають не лише закони розвитку економічних систем, а й аспекти еволюції людської свідомості, культури народу, його моралі, психології та поведінки, що впливають як на життя окремої людини, так і на прогрес економіки, адже основою економічної підготовки, яку має забезпечувати школа, є система економічних знань, певних умінь і навичок творчого практичного застосування, спрямованих на формування економічної свідомості та економічного мислення, світогляду, поглядів та переконань, економічної культури. 
Більш глибоке усвідомлення сутності окремих навчальних предметів покликане бути здійсненим через профільне навчання в школах. Н. Петрощук зазначає, що загальною тенденцією розвитку старшої профільної школи $\epsilon$ іï орієнтація на широку диференціацію, варіативність, багатопрофільність, інтеграцію загальної й допрофесійної підготовки [6, с. 8]. Отже, головне завдання сучасної школи формування й розвиток особистості на основі врахування індивідуальних особливостей, нахилів та інтересів, у тому числі й економічного напрямку.

До навчальних курсів економічного спрямування, що дають можливість розкритися потенціалу дитини ще в школі, належить, наприклад, курс «Основи підприємницької діяльності». Якщо теоретичні знання з цього курсу вдається підкріпити різними формами позаурочної діяльності (організація шкільного виробництва, сільськогосподарського товариства, тривалої ділової гри, конкурсів, вікторин, брейнринги тощо), то ефективність навчання значно зросте.

Поєднання (інтеграція) трудового навчання та економічних знань у старших класах шляхом використання різноманітних допрофесійних програм є дуже перспективним шляхом розвитку профільної старшої школи. На жаль, допрофесійні програми у школі сьогодні - це переважно скорочені вишівські курси 3 мікро-, макроекономіки, економіки підприємств, маркетингу, менеджменту тощо. Важливим для викладання економіки $\epsilon$ створення $\mathrm{i}$ застосування особистісно орієнтованої технології навчання, що допоможе вчителеві максимально наблизитися до роботи 3 кожним учнем. Звичайно, для цього необхідна комп’ютерна база. Комп'ютеризація набуває темпів, проте комп'ютерних програм для роботи на уроках економіки ще не достатньо.

Однією з провідних ідей Національної доктрини розвитку освіти у XXIст. $є$ розширення доступу учнів до здобуття якісної освіти. Відомо, що досі економіка була пріоритетним предметом переважно в елітних або спеціалізованих (профільних) школах. У цьому році кількість шкіл, у яких викладається економіка, значно зросла. Однак це відбулося переважно за рахунок великих i малих міст, i меншою мірою - сільських шкіл i шкіл-інтернатів. Змінити таке становище можна за допомогою системи дистанційного навчання. 
Отже, в дослідженні констатовано факт необхідності поширення економічних знань та підготовки молоді до умов ринкової системи господарювання, обгрунтовано доцільність підготовки кадрів - менеджерів, маркетологів, підприємців, банкірів, висококваліфікованих фахівців виробничої сфери. Доведено, що теоретична економічна підготовка учнів здійснюється з урахуванням того, що вітчизняна, економічна освіта швидко не конституюється на постулатах і концепціях марксистсько-ленінської теорії і зорієнтувалася на передові вчення і теорії країн з розвинутою ринковою економікою.

\section{Література}

1. Аксьонова О. В. Методика викладання економічних дисциплін : [навч. посіб.] / О. В. Аксьонова. - К. : КНЕУ, 2006. 708 с. 2. Вачевський М. В. Основи економіки: [навч. посіб. для учнів ліцеїв, коледжів, гімназій та загальноосвітніх шкіл 10-11-12 кл.] / М. Вачевський, В. Мадзігон. - К. : Педагогічна думка. 2007. - 612 с. 3. Енциклопедія освіти / В. Г. Кремінь (гол. ред.). К. : Юрінком Інтер, $2008 . \quad-1040$ с. 4. Нисимчук А. С. Экономическое образование школьников: [кн. для учителя] / А. С. Нисимчук. - М.: Просвещение, $1991 .-128$ с. 5. Падалка О. С. Економічне виховання в школі / О. С. Падалка // Трудова підготовка в закладах освіти. - 1998. - №4. - С. 29-32. 6. Петрощук Н. Профільне навчання в школах Києва / Н. Петрощук // Директор школи. - 2011. - №18. - С. 8-11. 7. Прокопенко И. Ф. Экономическое образование школьников: [учеб. пособ. для учит. сред. шк.] / И. Ф. Прокопенко, Е. Н. Камышанченко, В. И. Лозовая. - Х. : Основа, 1995. - 172 с. 8. Шпак О. Т. Економічна підготовка педагогічних кадрів в системі безперервної освіти / НПУ ім. Драгоманова. - К. : Четверта хвиля, 2000. - 352 с.

Ю. В. Курбатова, кандидат пед. наук, ст. викладач, Дніпропетровський державний аграрний університет

\section{ПРИНЦИПИ РОЗВИТКУ ПРОФЕСІЙНОГО СТАНОВЛЕННЯ МАЙБУТНЬОГО АГРОНОМА}

У статті наведено модель розвитку професійного становлення майбутнього агронома в навчально-виховному прочесі аграрного університету та докладно розглянуто принципи, щьо сприяють розвитку професійного становлення майбутнього агронома

Ключові слова: професійне становлення, розвиток професійного становлення, педагогічні принципи, педагогічні умови. 